\title{
FK506 (tacrolimus) causes pain sensation through the activation of transient receptor potential ankyrin 1 (TRPA1) channels
}

\author{
Tomo Kita $^{1} \cdot$ Kunitoshi Uchida $^{1} \cdot$ Kenichi Kato $^{1} \cdot$ Yoshiro Suzuki $^{2} \cdot$ Makoto Tominaga $^{2,3} \cdot$ Jun Yamazaki ${ }^{1}$
}

Received: 7 May 2018 / Accepted: 12 November 2018 / Published online: 26 November 2018

(c) The Physiological Society of Japan and Springer Japan KK, part of Springer Nature 2018

\begin{abstract}
FK506 (tacrolimus) is an immunosuppressant widely used as an ointment in the treatment of atopic dermatitis. However, local application of FK506 can evoke burning sensations in atopic dermatitis patients, and its mechanisms are unknown. In this study, we found that FK506 activates transient receptor potential ankyrin 1 (TRPA1) channels. In $\mathrm{Ca}^{2+}$-imaging experiments, increases in intracellular $\mathrm{Ca}^{2+}$ concentrations $\left(\left[\mathrm{Ca}^{2+}\right]_{\mathrm{i}}\right.$ ) by FK506 were observed in HEK293T cells expressing hTRPA1 or hTRPM8. FK506-induced currents were observed in HEK293T cells expressing hTRPA1 or mTRPA1, but less or not at all in cells expressing hTRPV1 or hTRPM8 using a patch-clamp technique. FK506 also evoked single-channel opening of hTRPA1 in an inside-out configuration. FK506-induced $\left[\mathrm{Ca}^{2+}\right]_{\mathrm{i}}$ increases were also observed in TRPA1-expressing mouse primary sensory neurons. Furthermore, injection of FK506 evoked licking or biting behaviors and these behaviors were almost abolished in TRPA1 knockout mice. These results indicate that FK506 might cause pain sensations through TRPA1 activation.
\end{abstract}

Keywords FK506 · Pain · TRPA1 · Sensory neuron · Adverse effect

\section{Introduction}

FK506 (also known as tacrolimus), a macrolide produced by Streptomyces tsukubaensis, is a calcineurin inhibitor and is widely used as an immunosuppressant after organ transplantation [1]. FK506 binds to FK506 binding protein 12 (FKBP-12), creating a complex [2, 3]. This complex further binds to calcium, calmodulin, and calcineurin,

Tomo Kita and Kunitoshi Uchida contributed equally to this work.

Electronic supplementary material The online version of this article (https://doi.org/10.1007/s12576-018-0647-z) contains supplementary material, which is available to authorized users.

Kunitoshi Uchida

uchida@college.fdcnet.ac.jp

1 Department of Physiological Science and Molecular Biology, Fukuoka Dental College, 2-15-1 Tamura,

Sawara-ku, Fukuoka 814-0193, Japan

2 Division of Cell Signaling, National Institute for Physiological Sciences, National Institutes of Natural Sciences, Okazaki 444-8787, Japan

3 Thermal Biology Group, Exploratory Research Center on Life and Living Systems, National Institutes of Natural Sciences, Okazaki 444-8787, Japan and inhibits calcineurin activation. This inhibition blocks the production of lymphokines and inflammatory cytokines such as interleukin-2, which is necessary for the proliferation and differentiation of lymphocytes. Calcineurin inhibitors, including FK506 and pimecrolimus, are also used as topical medications for the treatment of atopic dermatitis [4-6]. FK506 is reported to suppress cytokine production in T-cells in a fashion similar to steroids $[7,8]$, whereas the types of chemokines released from mast cells differ from those modulated by steroids [9]. FK506 ointment is available at concentrations of $0.1 \%$ for adults and $0.03 \%$ for children. It is frequently indicated for the face and neck where topical steroids are not recommended [10]. On the other hand, irritative symptoms such as transient burning pain or pruritus sensation often appear at the site of application, as adverse effects in atopic dermatitis patients, whereas most of these symptoms disappear with amelioration of the eruption [6, 11]. In particular, the most common local sensation is burning pain and its frequency is much higher than the sensation of itch [12-14]. However, the mechanisms underlying these adverse effects are largely unknown.

Most transient receptor potential (TRP) channels are $\mathrm{Ca}^{2+}$-permeable non-selective cation channels, and they are activated by a wide variety of sensory stimuli, including nociceptive compounds, oxidants, protons, touch and 
changes in osmolarity and temperature [15-17]. TRPV1, TRPV2, TRPV3, TRPV4, TRPM2, TRPM3, TRPM8, and TRPA1 are expressed in sensory neurons and/or skin [18-20] and are involved in the perception of the information about the external and internal environment. TRPA1 (transient receptor potential ankyrin 1) channel is mainly expressed in primary sensory neurons [21] and is involved in perception of painful stimuli. TRPA1 is activated by various stimuli, including alkaline $\mathrm{pH}[22], \mathrm{Ca}^{2+}$ and $\mathrm{Zn}^{2+}$ cations $[23,24]$, and pungent and/or noxious chemical compounds such as wasabi (AITC), pepper (piperin), garlic (allicin), cinnamon (cinnamaldehyde), Japanese pepper (sanshool), and olive (oleocanthal) [25-30]. Although its responsiveness to noxious cold and mechanical stimuli in mammals is still controversial [31-33], TRPA1 has attracted attention for its potential role in nociception $[32,34,35]$. In addition, TRPA1 is reported to be involved in a histamine-independent itch sensation. Many reports indicated that some drugs and cosmetics that cause irritation and painful sensations, such as parabens [36], cyclooxygenase inhibitors [37], menthol [38], propofol [39], and local anesthesia such as lidocaine [40], activate the TRPA1 channel. Activation of TRPA1 could cause irritation and pain sensations as adverse effects. Therefore, blockade of this channel might be a therapeutic approach in the treatment of pain syndromes.

In this study, to elucidate the mechanisms by which FK506 induces irritant sensations, we analyzed the effect of FK506 on TRP channels that are dominantly expressed in sensory neurons and the skin. We found that FK506 activates both mouse and human TRPA1. In addition, FK506 showed pain-related behaviors rather than itch-related behaviors through TRPA1 activation.

\section{Materials and methods}

\section{Cell culture}

Human embryonic kidney-derived 293T (HEK293T) cells were cultured in DMEM (Wako Pure Chemical Industries, Ltd., Osaka, Japan) containing 10\% FBS (Thermo Fisher Scientific Inc., MA, USA), 2 mM GlutaMAX (Thermo Fisher Scientific Inc.), 100 units/ml penicillin and $100 \mu \mathrm{g} /$ $\mathrm{ml}$ streptomycin (Thermo Fisher Scientific Inc.) at $37{ }^{\circ} \mathrm{C}$ in $5 \% \mathrm{CO}_{2}$. For calcium imaging, $1 \mu \mathrm{g}$ of human TRPV1 (hTRPV1), TRPV2 (hTRPV2), TRPV3 (hTRPV3), TRPV4 (hTRPV4), TRPA1 (hTRPA1) or TRPM8 (hTRPM8) in pcDNA3.1 (Thermo Fisher Scientific Inc.), and $0.1 \mu \mathrm{g}$ of pCMV-DsRed Express (Takara Bio Inc., Shiga, Japan) were transfected into HEK293T cells using Lipofectamine and Plus Reagent (Thermo Fisher Scientific Inc.) in OPTI-MEM (Thermo Fisher Scientific Inc.). For whole-cell patch-clamp recordings, $1 \mu \mathrm{g}$ of hTRPV1, hTRPA1, hTRPM8, or mouse
TRPA1 (mTRPA1) in pcDNA3.1, and $0.1 \mu \mathrm{g}$ of pGreen Lantern 1 (Thermo Fisher Scientific Inc.) were transfected into HEK293T cells. Mock cells were transfected with $1 \mu \mathrm{g}$ of empty vector with $0.1 \mu \mathrm{g}$ of pCMV-DsRed or pGreen Lantern 1. Transfected-HEK293T cells were incubated for $2-3 \mathrm{~h}$ at $37{ }^{\circ} \mathrm{C}$ in a $5 \% \mathrm{CO}_{2}$ atmosphere. After incubation, cells were reseeded on coverslips in DMEM and further incubated under the same conditions. After an additional day of incubation, transfected-HEK293T cells were used for $\mathrm{Ca}^{2+}$-imaging and whole-cell patch-clamp recording.

\section{Animals}

C57BL/6 N mice (males, 5-6 weeks old, Japan SLC Inc., Fukuoka, Japan) were used for extraction of dorsal root ganglion cells and pain behavior assays. TRPA1 knockout (TRPA1KO) mice were generously provided by Prof. D. Julius (UCSF, San Francisco, CA, USA). TRPM8 knockout (TRPM8KO) mice were graciously provided by Prof. A. Patapoutian (Scripps Research Institute, La Jolla, CA, USA). Both were used for behavioral experiments. Animals were housed in a controlled environment (12-h light/ dark cycle, room temperature $22-24{ }^{\circ} \mathrm{C}, 50-60 \%$ relative humidity) with free access to food and water. All procedures involving the care and use of animals were approved by The Institutional Animal Care and Use Committee of National Institutes of Natural Sciences, and Animal Research Committee of Fukuoka Dental College, and performed in accordance with the Guide for the Care and Use of Laboratory Animals (National Institutes of Health publication number 85-23, revised 1985).

\section{Primary culture of mouse dorsal root ganglion neurons}

Dorsal root ganglia (DRG) were rapidly dissected from adult male wild-type (WT) C57BL/6 N mice and treated with $2.5 \mathrm{mg} / \mathrm{ml}$ collagenase (Sigma-Aldrich, MO, USA) in MEM complete for $20 \mathrm{~min}$ at $37^{\circ} \mathrm{C}$. MEM complete consisted of Earle's Balanced Salt Solution (Sigma-Aldrich) containing $10 \%$ FBS, 50 units $/ \mathrm{ml}$ penicillin, $50 \mu \mathrm{g} / \mathrm{ml}$ streptomycin, 2 mM GlutaMAX and MEM Vitamin Solution (Sigma-Aldrich). After incubation, cells were resuspended and mechanically dissociated in MEM complete. Dissociated cells were centrifuged and plated on coverslips coated by $1 \mathrm{mg} / \mathrm{ml}$ poly-D-lysine (Sigma-Aldrich). After incubation for $10-15 \mathrm{~h}$ in $5 \% \mathrm{CO}_{2}$ at $37^{\circ} \mathrm{C}$, cells were used for $\mathrm{Ca}^{2+}$-imaging experiment.

\section{Chemicals}

FK506, tacrolimus monohydrate (Tokyo Chemical Industry Co., Ltd., Tokyo, Japan) was dissolved in dimethyl 
sulfoxide (DMSO, Wako Pure Chemical Industries, Ltd.) at a concentration of $10 \mathrm{mM}$. A967079 (Sigma-Aldrich), 2-aminoethoxydiphenylborane (2-APB, Sigma-Aldrich), GSK1016790A (Sigma-Aldrich), ionomycin (Wako Pure Chemical Industries, Ltd.), Fura-2AM (Molecular Probes, Thermo Fisher Scientific Inc.) and Fluo-4AM (Molecular Probes, Thermo Fisher Scientific Inc.) were dissolved in DMSO. Capsaicin (Wako Pure Chemical Industries, Ltd.), menthol (Wako Pure Chemical Industries, Ltd.) and carvacrol (Sigma-Aldrich) were dissolved in ethanol (Wako Pure Chemical Industries, Ltd.). Allyl isothiocyanate (AITC, Wako Pure Chemical Industries, Ltd.) was dissolved in methanol (Wako Pure Chemical Industries, Ltd.). The concentration of all solvents was no more than $0.1 \%$ in the bath solution except FK506. $55 \mu \mathrm{M}$ FK506 bath solution contained $0.55 \%$ DMSO, and $30 \mu \mathrm{M}$ FK506 bath solution contained $0.3 \%$ DMSO.

\section{$\mathrm{Ca}^{2+}$-imaging}

HEK293T cells and neurons were loaded with $5 \mu \mathrm{M}$ Fura$2 \mathrm{AM}$ or $5 \mu \mathrm{M}$ Fluo-4AM for more than $40 \mathrm{~min}$. After incubation, coverslips were put in an open chamber (Warner Instruments LLC, CT, USA) and were superfused with a standard bath solution containing $140 \mathrm{mM} \mathrm{NaCl}, 5 \mathrm{mM}$ $\mathrm{KCl}, 2 \mathrm{mM} \mathrm{CaCl}, 2 \mathrm{mM} \mathrm{MgCl}, 10 \mathrm{mM}$ D-glucose and 10 mM HEPES (pH7.4 with $\mathrm{NaOH}$ ) at room temperature. Images of Fura-2-loaded or Fluo-4-loaded cells were captured every $3 \mathrm{~s}$ with a CoolSNAP ES CCD camera (Photometrics, AZ, USA). Intracellular free $\mathrm{Ca}^{2+}$ concentrations $\left(\left[\mathrm{Ca}^{2+}\right]_{\mathrm{i}}\right)$ in HEK293T cells were measured by dual-wavelength Fura-2 microfluorometry with excitation at $340 / 380 \mathrm{~nm}$ and emission at $510 \mathrm{~nm}$. The ratio was calculated and acquired using an imaging processing system (IP-Lab, Scanalytic Inc., VA, USA). For mouse DRG neurons, $\left[\mathrm{Ca}^{2+}\right]_{i}$ was measured with Fluo- 4 with excitation at $488 \mathrm{~nm}$ and emission at $510 \mathrm{~nm}$. Images were acquired using NIS elements software (NIKON Corp., Tokyo, Japan). The viability of HEK293T cells and mouse DRG neurons was confirmed by responses to $5 \mu \mathrm{M}$ ionomycin. Mouse DRG neurons were identified by the response to $50 \mathrm{mM} \mathrm{KCl}$. For HEK293T cells transfected with each of the TRP channel genes, cells showing an increase in the ratio of more than 0.3 from basal values in response to agonists were defined as TRP channel-expressing cells. The $\Delta$ Ratio value was normalized to the peak response induced by $5 \mu \mathrm{M}$ ionomycin. The ratio of the fluorescence intensities of the two wavelengths of Fura-2 and fluorescence intensity of Fluo- 4 was analyzed for changes in the fluorescence intensity within regions of interests (ROIs) using ImageJ (National Institutes of Health, Bethesda, MD, USA). Cells showing an increase in the fluorescence intensity (arbitrary units) of more than 30 from basal values in response to FK506 were defined as FK506sensitive cells. Similarly, cells showing an increase in the fluorescence intensity of more than 50 from basal values in response to AITC or capsaicin were defined as AITC- or capsaicin-positive cells. All experiments were performed at room temperature.

\section{Electrophysiology}

For whole-cell patch-clamp recordings, HEK293T cells were transfected with hTRPV1, hTRPA1, hTRPM8, or mTRPA1 on coverslips that were put in a chamber and superfused with standard bath solution (the same as that described for $\mathrm{Ca}^{2+}$-imaging experiments). The pipette solution contained $140 \mathrm{mM} \mathrm{KCl}, 5 \mathrm{mM}$ EGTA, and $10 \mathrm{mM}$ HEPES (pH 7.4 with $\mathrm{KOH})$. Data were sampled at $10 \mathrm{kHz}$ and filtered at $5 \mathrm{kHz}$ for analysis (Axon 200B amplifier with pCLAMP10 software, Axon Instruments, Union City, CA, USA). Membrane potential was clamped at $-60 \mathrm{mV}$ and voltage ramppulses from -100 to $+100 \mathrm{mV}(300 \mathrm{~ms})$ were applied every 3 s. For inside-out single channel recordings, HEK293T cells transfected with hTRPA1 gene on coverslips were put in a chamber. The bath solution and the pipette solution contained $140 \mathrm{mM} \mathrm{KCl}, 5 \mathrm{mM}$ EGTA, and $10 \mathrm{mM}$ HEPES (pH 7.4 with $\mathrm{KOH}$ ). Data were sampled at $10 \mathrm{kHz}$ and filtered at $2 \mathrm{kHz}$ for analysis (Axon 200B amplifier with pCLAMP10 software). The membrane potential was clamped at $+30 \mathrm{mV}$. All experiments were performed at room temperature.

\section{Pain-related and itch-related behavior tests}

WT C57BL/6 N, TRPA1KO and TRPM8KO mice were used in these experiments. These mice were kept individually in transparent cages $(15 \times 23 \times 14 \mathrm{~cm})$ for more than 30 min before experiments. Licking or biting behaviors were observed by using the same method as we performed previously [22, 41]. In detail, $20 \mu \mathrm{l}$ of 0.3 or $1 \mathrm{mM} \mathrm{FK506}$ (6.7 or $20 \mathrm{nmol}$ injection/site) dissolved in saline containing $20 \%$ DMSO or vehicle were injected into the planta of mouse hind-paws, and we immediately counted the time spent licking or biting for $10 \mathrm{~min}$. Itch-related behavior was assessed using the model reported by Kuraishi and his colleagues [42]. In detail, the backs of mice were shaved before itch-related experiments; $50 \mu \mathrm{l}$ of $400 \mu \mathrm{M}$ FK506 (20 nmol injection/site) dissolved in saline containing $20 \%$ DMSO or vehicle was intradermally injected into the skin on the back. The mice generally scratched themselves several times for about $1 \mathrm{~s}$ and a series of such movements was counted as one incidence of scratching. After injection, the number of scratching incidents at the administration site by the hind paw was counted for $15 \mathrm{~min}$. 


\section{Statistical analysis}

Data are expressed as mean \pm SEM. Statistical analysis was performed by the unpaired two-tailed Student's $t$ test for comparison between two groups. For comparison of multiple groups, statistical analysis was performed by the one-way ANOVA followed by the post hoc Bonferroni's test using OriginPro 9 (OriginLab Corp., Northampton, MA, USA). $P<0.05$ was defined as statistically significant.

\section{Results}

\section{FK506 activated human TRPA1 in a heterologous expression system}

We used a $\mathrm{Ca}^{2+}$-imaging experiment to determine whether FK506 activated hTRPV1, hTRPV2, hTRPV3, hTRPV4, hTRPA1, and hTRPM8 channels. Application of $30 \mu \mathrm{M}$ FK506 caused very little $\left[\mathrm{Ca}^{2+}\right]_{\mathrm{i}}$ increases in HEK293T cells expressing hTRPV1 (Fig. 1b), and large $\left[\mathrm{Ca}^{2+}\right]_{\mathrm{i}}$ increases in HEK293T cells expressing hTRPA1 or hTRPM8 (Fig. 1f, g). In contrast, $\left[\mathrm{Ca}^{2+}\right]_{\mathrm{i}}$ increases were not observed in HEK293T cells expressing hTRPV2, hTRPV3, or hTRPV4 (Fig. 1c-e). The summary of $\triangle$ Ratio values also indicated that the cells expressing hTRPA1 or hTRPM8 responded to $30 \mu \mathrm{M}$ and $55 \mu \mathrm{M}$ FK506. The cells expressing hTRPV1 tended to respond to $30 \mu \mathrm{M}$ FK506 (Fig. 1h).

We next examined the effect of FK506 on hTRPV1, hTRPM8, and hTRPA1 channels by whole-cell patchclamp recordings. No inward currents (at $-60 \mathrm{mV}$ ) were observed in HEK293T cells expressing hTRPV1 or hTRPM8 after treatment with $55 \mu$ M FK506 alone. In contrast, in HEK293T cells expressing hTRPM8, we observed small outward currents at positive potentials during pulses ramped from -100 to $+100 \mathrm{mV}$ every $3 \mathrm{~s}$ (Fig. 2). We did not pursue concentrations higher than $55 \mu \mathrm{M}$ because of the solubility of FK506. On the other hand, application of $55 \mu \mathrm{M}$ FK506 caused both outward and inward currents in HEK293T cells expressing hTRPA1 (Fig. 3a). A current-voltage $(I-V)$ curve from -100 to $+100 \mathrm{mV}$ in the presence of $55 \mu \mathrm{M}$ FK506 crossed the origin and showed outward rectification, which is consistent with the $I-V$ relationship of TRPA1 [21] (Fig. 3a). The currents evoked by $55 \mu \mathrm{M}$ FK506 were inhibited by $3 \mu \mathrm{M}$ A967079, a TRPA1 antagonist (Fig. 3b), whereas the current recovery by FK506 was not observed once the TRPA1 antagonist was applied. This irreversibility was also observed in a $\mathrm{Ca}^{2+}$-imaging experiment using HEK293T cells expressing hTRPA1 (Supplemental Fig. 1). We then analyzed the dose-response profile. As shown in Fig. 3c, d, current densities at $-60 \mathrm{mV}$ (C) and $+100 \mathrm{mV}$ (D) in the presence of $30 \mu \mathrm{M}$ FK506 were not significantly different between mock-transfected and hTRPA1-transfected HEK293T cells. Application of $55 \mu \mathrm{M}$ FK506 showed significantly greater current densities at both $-60 \mathrm{mV}(\mathrm{C})$ and $+100 \mathrm{mV}(\mathrm{D})$ in HEK293T cells expressing hTRPA1 compared to those in mock-transfected HEK293T cells, whereas current densities at $100 \mathrm{mV}$ were greater than those at $60 \mathrm{mV}$ (Fig. 3c, d).

In order to examine whether FK506 activates TRPA1 in a membrane-delimited manner, we performed single-channel recordings with an inside-out configuration in HEK293T cells expressing hTRPA1. Figure $3 e$ shows representative current traces of single-channel openings in HEK293T cells expressing hTRPA1. Single-channel currents were observed not only by application of $55 \mu \mathrm{M}$ FK506, but also by application of $20 \mu \mathrm{M}$ AITC. On the other hand, the currents were not induced by $55 \mu \mathrm{M}$ FK506 in mock-transfected HEK293T cells (data not shown). The calculated unitary conductance of FK506-activated current was 104.1 $\pm 13.4 \mathrm{pS}(n=4)$, and a similar value was obtained for AITC-activated currents $(98.8 \pm 12.3 \mathrm{pS}, n=4)$. These properties at the single-channel level support the idea that TRPA1 can be activated by FK506 directly or through structures retained even in a small excised membrane patch. We then analyzed the NPo (channel number $\mathrm{x}$ open probability) to assess TRPA1 activation by FK506. The NPo during application of $55 \mu \mathrm{M}$ FK506 was significantly higher than the basal level, and tended to be lower than that of $20 \mu \mathrm{M}$ AITC (Fig. 3f).

\section{FK506 activated mouse TRPA 1 in both heterologous expression systems and primary sensory neurons}

We confirmed the effect of FK506 on mTRPA1 by wholecell patch-clamp recordings. Application of $55 \mu \mathrm{M}$ FK506 caused both inward and outward currents in HEK293T cells expressing mTRPA1 (Fig. 4a). Current densities at $-60 \mathrm{mV}$ in $55 \mu \mathrm{M}$ FK506 in HEK293T cells expressing mTRPA1 were significantly larger than those in mock-transfected HEK293T cells (Fig. 4b).

We next examined the effect of FK506 on native mTRPA1 by using mouse DRG neurons. Figure 5a shows representative traces of $\left[\mathrm{Ca}^{2+}\right]_{i}$ changes in each mouse DRG neuron. Application of $30 \mu \mathrm{M}$ FK506 increased $\left[\mathrm{Ca}^{2+}\right]_{\mathrm{i}}$ in some mouse DRG neurons (Fig. 5a). We then classified the mouse DRG neurons by the response to AITC and capsaicin to determine TRPA1-expressing and TRPV1-expressing neurons. In a total of 186 cells, $24.2 \%$ of the neurons responded to $30 \mu \mathrm{M}$ FK506 (Fig. 5b). In FK506-responding neurons, $42.2 \%$ of the cells (19 in 45 neurons) were positive for AITC. Furthermore, $29.7 \%$ of the AITC-positive neurons responded to FK506 (19 in 64 neurons). Increases in $\left[\mathrm{Ca}^{2+}\right]_{\mathrm{i}}$ by $30 \mu \mathrm{M}$ FK506 were not observed in the absence of extracellular $\mathrm{Ca}^{2+}$ (Fig. 5c), indicating that increases in $\left[\mathrm{Ca}^{2+}\right]_{\mathrm{i}}$ by $30 \mu \mathrm{M}$ FK506 

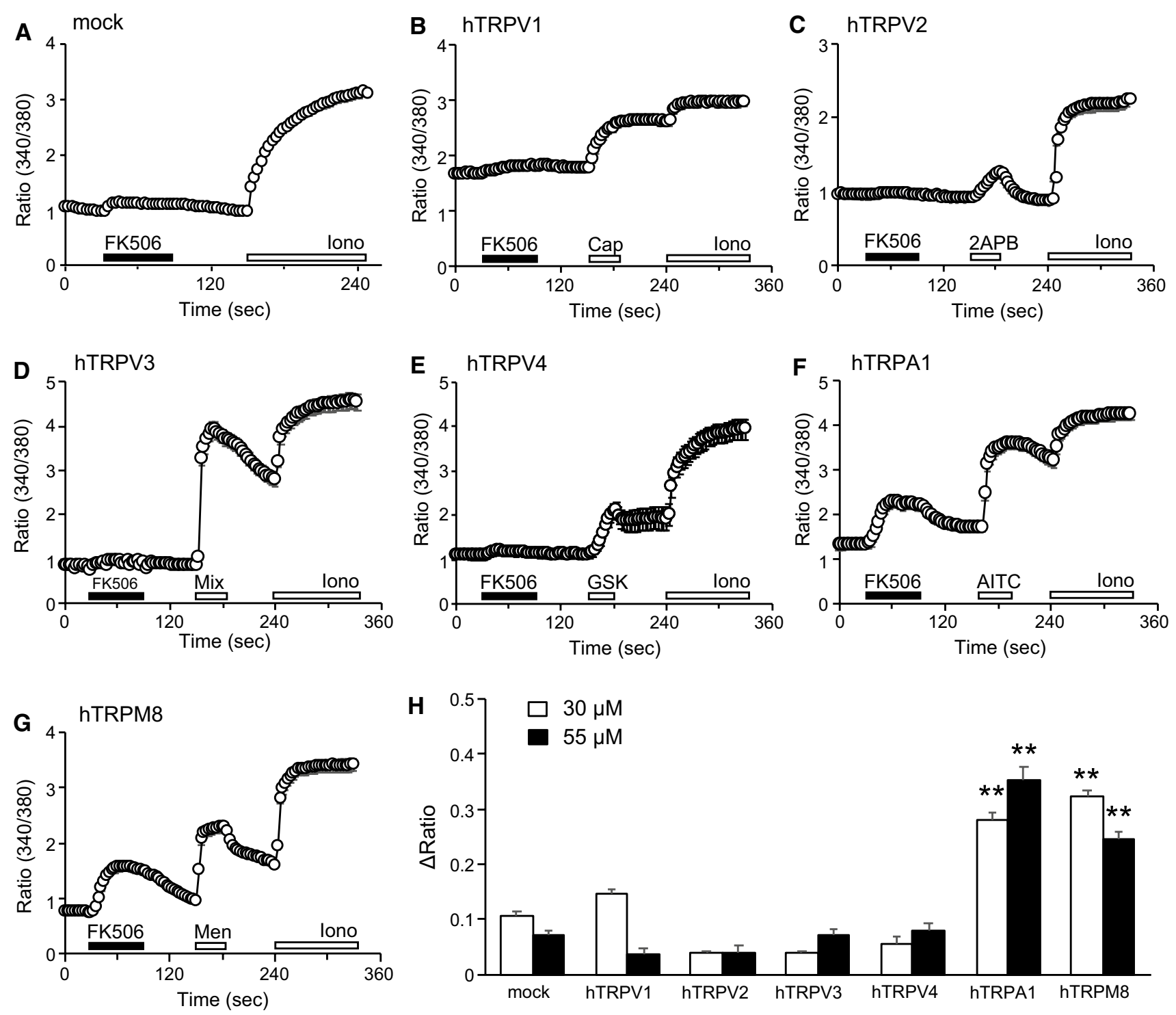

Fig. 1 Increased intracellular $\mathrm{Ca}^{2+}$ concentrations were observed after application of FK506 in HEK293T cells expressing human TRPA1 and TRPM8. a-g Representative changes in intracellular $\mathrm{Ca}^{2+}$ concentrations $\left(\left[\mathrm{Ca}^{2+}\right]_{\mathrm{i}}\right)$ stimulated by $30 \mu \mathrm{M}$ FK506 in mocktransfected HEK293T cells (a), or HEK293T cells expressing human TRPV1 (hTRPV1, b), TRPV2 (hTRPV2, c), TRPV3 (hTRPV3, d), TRPV4 (hTRPV4, e), TRPA1(hTRPA1, f) or TRPM8 (hTRPM8, g). To confirm the expression of each TRP channel, $1 \mu \mathrm{M}$ capsaicin (Cap), $500 \mu \mathrm{M}$ 2-aminoethyl diphenylborinate (2APB), a mixture of $250 \mu \mathrm{M} 2 \mathrm{APB}$ and $500 \mu \mathrm{M}$ carvacrol (Mix), $300 \mathrm{nM}$ GSK1016790A (GSK), $100 \mu \mathrm{M}$ allyl isothiocyanate (AITC), or $500 \mu \mathrm{M}$ menthol (Men) was used. Cell viability was checked by application of $5 \mu \mathrm{M}$

occurred through $\mathrm{Ca}^{2+}$ influx from the extracellular space. Increases in $\left[\mathrm{Ca}^{2+}\right]_{\mathrm{i}}$ by $30 \mu \mathrm{M}$ FK506 were almost abolished in AITC-positive neurons by application of $3 \mu \mathrm{M}$ A967079 (Fig. 5d), although inhibition by A967079 was irreversible (also described above). ionomycin (Iono). Y-axis: Fura-2 ratio $(340 \mathrm{~nm} / 380 \mathrm{~nm})$. Each symbol represents mean \pm SEM from 33 to 105 cells. h Summary of $\left[\mathrm{Ca}^{2+}\right]_{\mathrm{i}}$ increases following application of $30 \mu \mathrm{M}$ (white column) or $55 \mu \mathrm{M}$ (black column) of FK506 to HEK293T cells expressing hTRPV1, hTRPV2, hTRPV3, hTRPV4, hTRPA1 or hTRPM8. $Y$ axis: $\Delta$ Ratio calculated by the normalization of peak Fura- 2 ratio $(340 \mathrm{~nm} / 380 \mathrm{~nm})$ of FK506 to that of ionomycin. "Mock" indicates the $\left[\mathrm{Ca}^{2+}\right]_{\mathrm{i}}$ increases in HEK293T cells transfected with empty vector. Each column represents the mean + SEM from 22 to 184 cells. Statistical significance was assessed using ANOVA followed by a two-tailed multiple $t$ test with Bonferroni correction. **, $P<0.01$ vs. mock

\section{FK506 causes licking or biting behaviors but not scratching behaviors in mice}

To clarify whether FK506 caused pain and itching sensations, we performed in vivo experiments. We observed painrelated behaviors (licking or biting) induced by intraplantar 


\section{A hTRPV1}

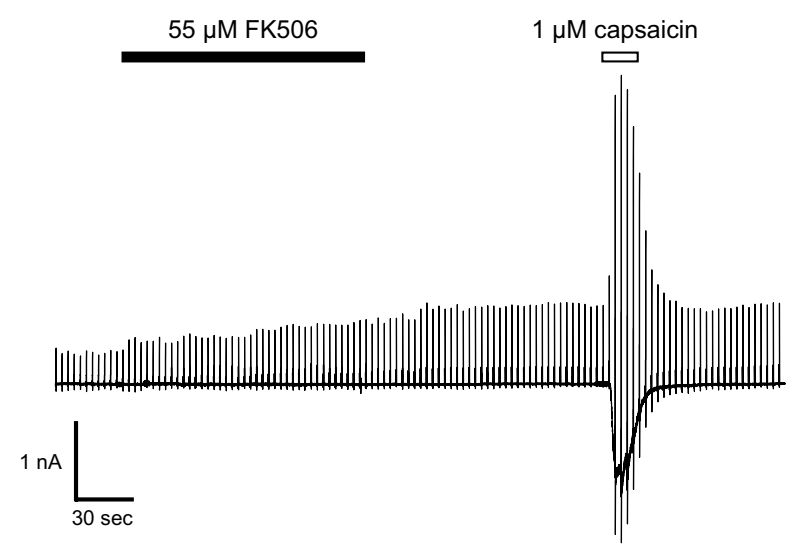

B hTRPM8

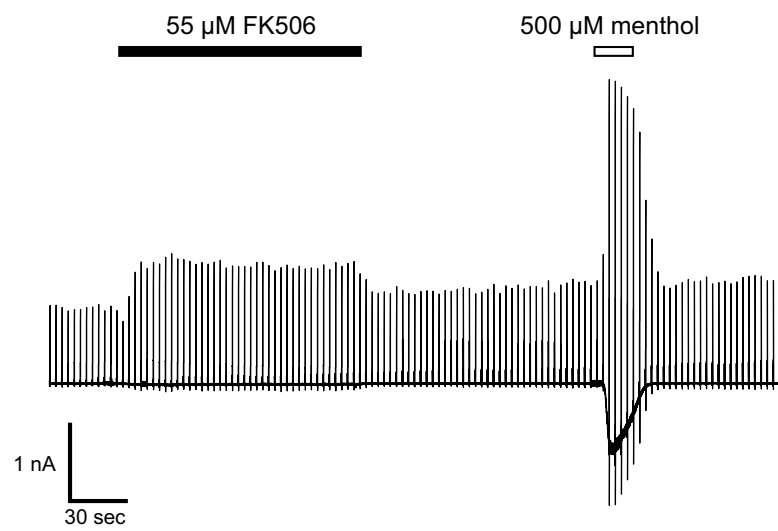

Fig. 2 FK506-induced inward currents were not observed in HEK293T cells expressing human TRPV1 or TRPM8. a A representative trace of whole-cell patch-clamp recording in HEK293T cells expressing human TRPV1 (hTRPV1) exposed to $55 \mu \mathrm{M}$ FK506 (black bar) and $1 \mu \mathrm{M}$ capsaicin (white bar). Membrane potential was held at $-60 \mathrm{mV}$ and ramp-pulses from -100 to $+100 \mathrm{mV}$ were applied every $3 \mathrm{~s}$. b A representative trace of whole-cell patch-clamp recording in HEK293T cells expressing human TRPM8 (hTRPM8) exposed to $55 \mu \mathrm{M}$ FK506 (black bar) and $500 \mu \mathrm{M}$ menthol (white bar). Membrane potential was held at $-60 \mathrm{mV}$ and ramp pulses from -100 to $+100 \mathrm{mV}$ were applied every $3 \mathrm{~s}$

injection of FK506 in mice. First, we checked the dosedependency. Although injection of $10 \mu \mathrm{l}$ of $1 \mathrm{mM}$ FK506 $(10 \mathrm{nmol})$ solution did not cause significant licking or biting behaviors, injection of $20 \mu \mathrm{l}$ of $1 \mathrm{mM}$ FK506 (20 nmol) solution induced licking or biting behaviors compared to that of $10 \mu \mathrm{l}$ of $20 \%$ DMSO-saline (vehicle) or $10 \mu \mathrm{l}$ of $1 \mathrm{mM}$ FK506 (10 nmol) (Supplemental Fig. 2). The time spent licking or biting was significantly longer in WT mice injected with $20 \mu \mathrm{l}$ of $1 \mathrm{mM}$ FK506 (20 nmol) than those injected with $20 \mu \mathrm{l}$ of vehicle (Fig. 6a and Supplemental Fig. 2). On the other hand, $20 \mu \mathrm{l}$ of $0.3 \mathrm{mM}$ FK506 (6.7 nmol) did not cause significant licking or biting behaviors in WT mice
(Fig. 6a). Unfortunately, high doses of FK506 could not be used because of its low solubility. Licking or biting induced by $20 \mathrm{nmol}$ FK506 was significantly impaired in TRPA1KO mice (Fig. 6b). On the other hand, intraplantar injection of $20 \mathrm{nmol}$ FK506 induced licking or biting behaviors in TRPM8KO mice to the extent similar to WT mice (Fig. 6c), whereas FK506 weakly activated hTRPM8 as shown in the whole-cell patch-clump recording (Fig. 2b), indicating that TRPM8 might not be involved in FK506-induced licking or biting behaviors. We next examined itching-related behaviors induced by intradermal injection of FK506 into the back skin. As shown in Fig. 6d, FK506 did not induce scratching behaviors in WT mice.

\section{Discussion}

In this study, we demonstrated that FK506 activates both human and mouse TRPA1. In mouse DRG neurons, some of the neurons including both AITC-sensitive and -insensitive neurons showed $\left[\mathrm{Ca}^{2+}\right]_{\mathrm{i}}$ increases stimulated by FK506. In addition, FK506-induced licking and biting behaviors were impaired in TRPA1KO mice, suggesting that FK506 causes pain sensations through TRPA1 activation.

Within TRP channels, which are expressed in sensory neurons and skin keratinocytes, FK506 induced $\left[\mathrm{Ca}^{2+}\right]_{\mathrm{i}}$ increases in HEK293T cells expressing hTRPA1 or hTRPM8 (Fig. 1). On the other hand, in whole-cell patch-clamp recordings, FK506-induced currents were observed in HEK293T cells expressing hTRPA1, indicating that hTRPA1 can be activated by FK506 (Fig. 3a-d). In HEK293T cells expressing hTRPM8, application of FK506 exhibited only an outward current at $+100 \mathrm{mV}$ and no inward currents at $-60 \mathrm{mV}$, indicating that its activity on TRPM8 is weak (Fig. 2b). Although some reports suggested the involvement of TRPV1 in the actions of FK506 [43, 44], FK506-induced TRPV1 currents were not observed in our experiments (Fig. 2a). Since one report showed that FK506 enhanced substance P release through phosphorylation of TRPV1 in primary sensory neurons [45], FK506 could modulate TRPV 1 activity but not directly activate it. Thus, our data demonstrate that FK506 acts on TRPA1 more effectively than on other TRP channels. It is well known that the chemical sensitivities of TRPA1 differ between species. For example, caffeine activates mTRPA 1 and inhibits hTRPA1 [46], and menthol activates hTRPA1 and inhibits mTRPA1 at high concentrations [38]. In this study, we observed that FK506 activates not only hTRPA1 but also mTRPA1 (Figs. 3, 4), suggesting that the effects of FK506 on TRPA1 are shared in between human and mouse.

We observed that FK506 caused $\left[\mathrm{Ca}^{2+}\right]_{\mathrm{i}}$ increases in $24.2 \%$ of mouse primary sensory neurons, and that $42.2 \%$ of FK506-positive neurons were sensitive to AITC (Fig. 5a, 
A hTRPA1

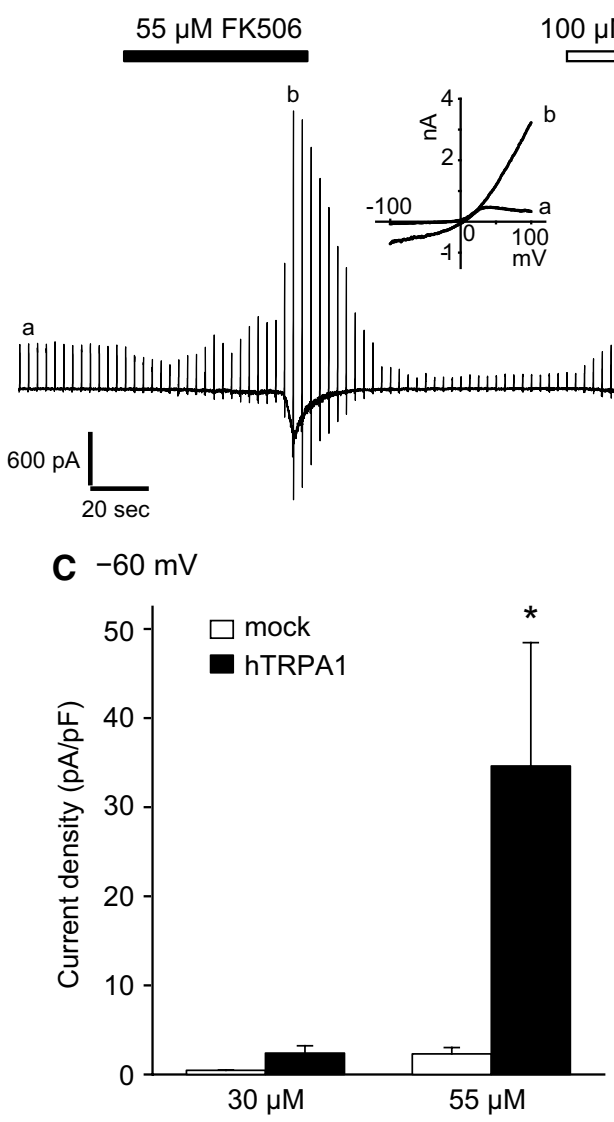

E

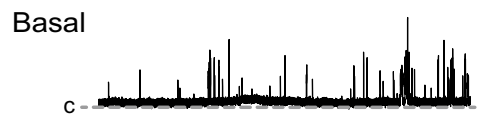

55 нM FK506

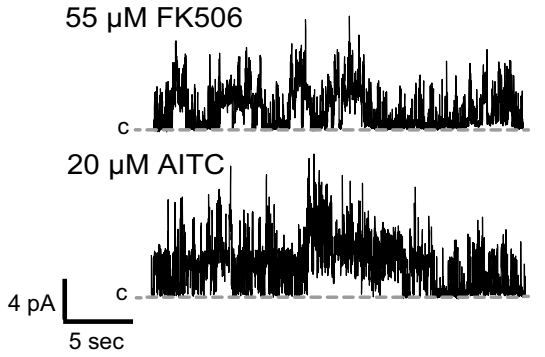

B hTRPA1

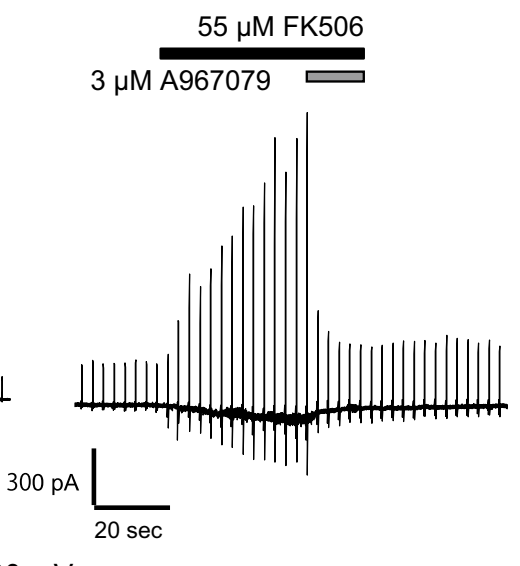

D $+100 \mathrm{mV}$
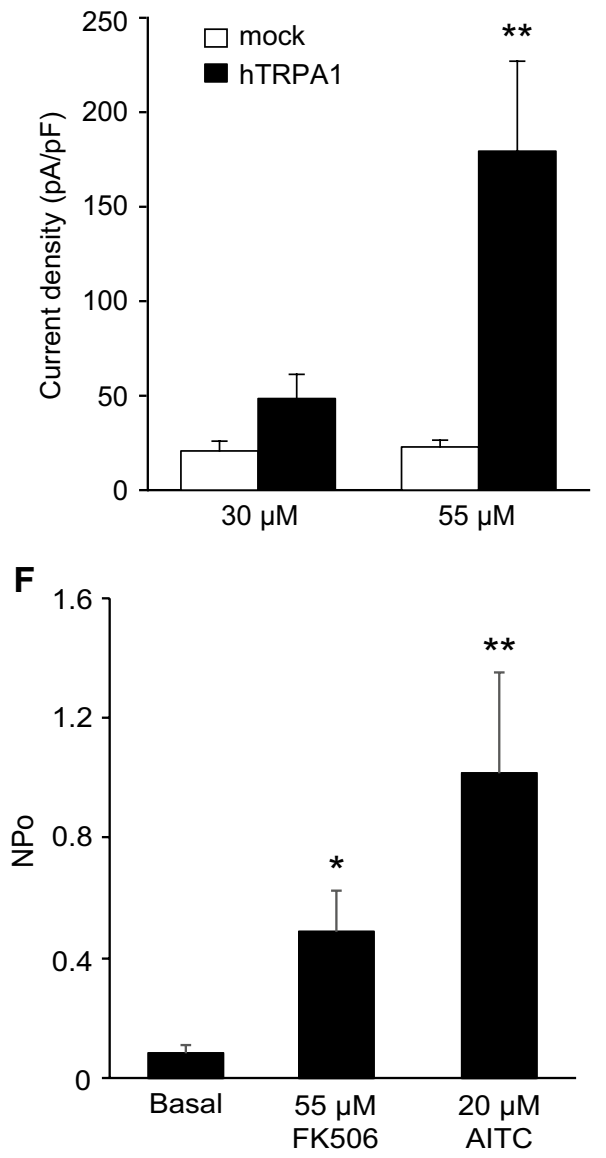

Each column represents the mean + SEM from 8-9 cells. Statistical significance was assessed using ANOVA followed by a two-tailed multiple $t$ test with Bonferroni correction. *, $P<0.05$; **, $P<0.01$ vs. mock. e Representative traces of inside-out single channel recordings in HEK293T cells expressing hTRPA1 in the absence (basal) or presence of $55 \mu \mathrm{M}$ FK506, or $20 \mu \mathrm{M}$ AITC. Dotted lines indicate 0 current levels (c). Membrane potential was held at $+30 \mathrm{mV}$. f NPo values were calculated in the single-channel currents. Ordinates: NPo (channel number $\times$ open probability). Each column represents the mean + SEM from four experiments. Statistical significance was assessed using ANOVA followed by a two-tailed multiple $t$ test with Bonferroni correction. *; $P<0.05$, **; $P<0.01$ vs. basal 
A mTRPA 1

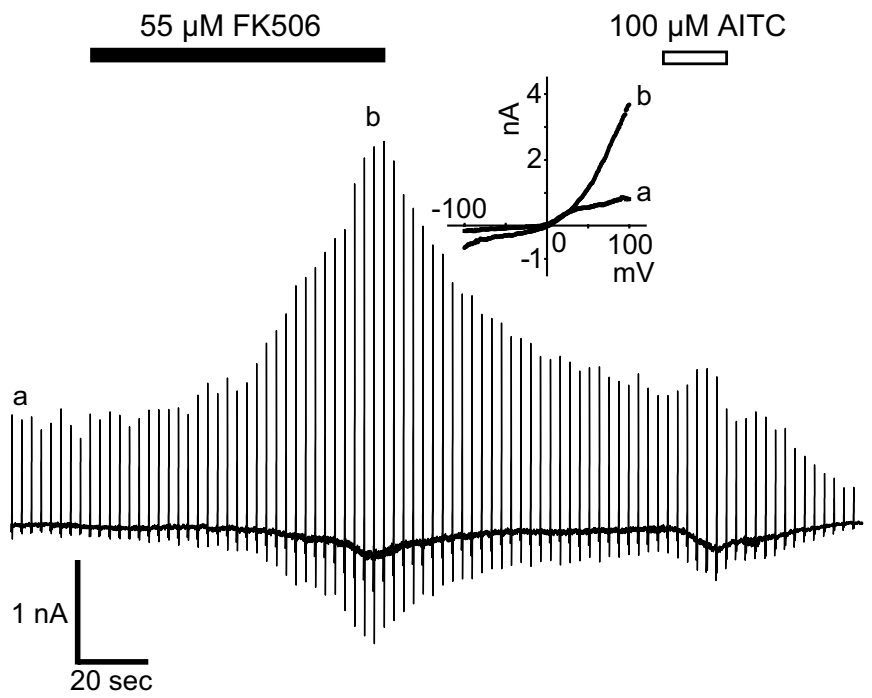

B $-60 \mathrm{mV}$

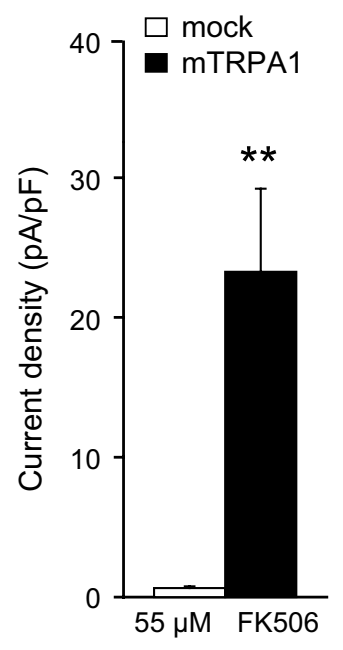

Fig. 4 FK506 activates mouse TRPA1. a A representative trace of whole-cell patch-clamp recording in a HEK293T cell expressing mouse TRPA1 (mTRPA1) exposed to $55 \mu \mathrm{M}$ FK506 (black bar) and $100 \mu \mathrm{M}$ AITC (white bar). Membrane potential was held at $-60 \mathrm{mV}$ and ramp pulses from -100 to $+100 \mathrm{mV}$ were applied every $3 \mathrm{~s}$. Insets indicate the representative $I-V$ curves of the mTRPA1 currents

b). In contrast to the results from HEK293T cells expressing mTRPA1, not all AITC-sensitive neurons responded to FK506 (Fig. 5a, b). One possibility is differences in the expression levels of the TRPA1 channel. Alternatively, the modulation levels of TRPA1 (e.g., hydroxylation by prolyl hydroxylases [47]) could be different among neurons. Another possibility is that other molecules expressed in some TRPA1-expressing neurons are necessary for activation of TRPA1-expressing primary sensory neurons, since FKBP is reported to interact with some TRP channels [48]. In this study, we found that application of a TRPA1 antagonist inhibited $\left[\mathrm{Ca}^{2+}\right]_{\mathrm{i}}$ increases by FK506 in AITC-sensitive neurons (Fig. 5d). Although we cannot discount the possibility of involvement of molecules that interact with FK506 in TRPA1-expressing sensory neurons, FK506 could directly activate native TRPA1 in mouse sensory neurons, which is consistent with the results from inside-out single-channel recordings (Fig. 3e, f). In contrast, FK506 increased $\left[\mathrm{Ca}^{2+}\right]_{\mathrm{i}}$ in AITC-insensitive primary sensory neurons $(57.8 \%$ of FK506-sensitive neurons, Fig. 5a, b), indicating the existence of other target molecules of FK506. TRPM8, which is not colocalized with TRPA1 in peripheral neurons [21, 49], is a candidate because we found that FK506 increased $\left[\mathrm{Ca}^{2+}\right]_{\mathrm{i}}$ in HEK293T cells expressing TRPM8 (Fig. 1). TRPC channels are also candidates for causing $\left[\mathrm{Ca}^{2+}\right]_{\mathrm{i}}$ influx upon FK506 application based upon the observations that FKBP12 interacts with TRPC3, TRPC6, or TRPC7, in the absence (a) or presence (b) of $55 \mu \mathrm{M}$ FK506. b Summary of the peak currents at $-60 \mathrm{mV}$ induced by $55 \mu \mathrm{M}$ FK506 in mTRPA1or mock-transfected HEK293T cells. Each column represents the mean + SEM from 8 to 9 cells. Statistical significance was assessed using Student's $t$ test. ${ }^{* *} ; P<0.01$ vs. mock

and FKBP52 associates with TRPC1, TRPC4, or TRPC5 [48]. Moreover, TRPC1, TRPC3, TRPC5, and TRPC6 were reported to be expressed in sensory neurons [50, 51]. Furthermore, TRP channels as well as other channels could underlie $\left[\mathrm{Ca}^{2+}\right]_{\mathrm{i}}$ changes induced by FK506, since some reports indicated that calcineurin inhibitors might modulate $\left[\mathrm{Ca}^{2+}\right]_{\mathrm{i}}$ changes through the interaction with voltage-gated calcium channels, ryanodine receptors and $\mathrm{IP}_{3}$ receptors $(50,51,52,53,54)$. In this study, we found that FK506induced $\left[\mathrm{Ca}^{2+}\right]_{\mathrm{i}}$ increases were completely abolished when there was no extracellular $\mathrm{Ca}^{2+}$ (Fig. 5c), indicating that $\left[\mathrm{Ca}^{2+}\right]_{\mathrm{i}}$ increases are due to $\mathrm{Ca}^{2+}$ influx from extracellular spaces, but not through $\mathrm{Ca}^{2+}$ release from intracellular $\mathrm{Ca}^{2+}$ stores. Thus, it is unlikely that ryanodine and $\mathrm{IP}_{3}$ receptors are involved in $\left[\mathrm{Ca}^{2+}\right]_{\mathrm{i}}$ increases during FK506 treatment of mouse sensory neurons. Taking these observations into consideration, it is possible that some of the neurons expressing TRPM8, TRPC3, TRPC5, or TRPC6 respond to FK506, or, alternatively, that other ion channels could be involved in FK506-induced $\left[\mathrm{Ca}^{2+}\right]_{\mathrm{i}}$ increases. Additional experiments will be necessary to clarify this point.

Many reports have demonstrated that FK506 induces chronic pain in humans, and its interacting proteins (FKBP and calcineurin) could be involved in chronic pain. Chronic pain was observed in transplant patients treated with calcineurin inhibitors $[52,53]$. Knockdown of FKBP51 reduced pro-inflammatory cytokines (TNF- $\alpha$, 

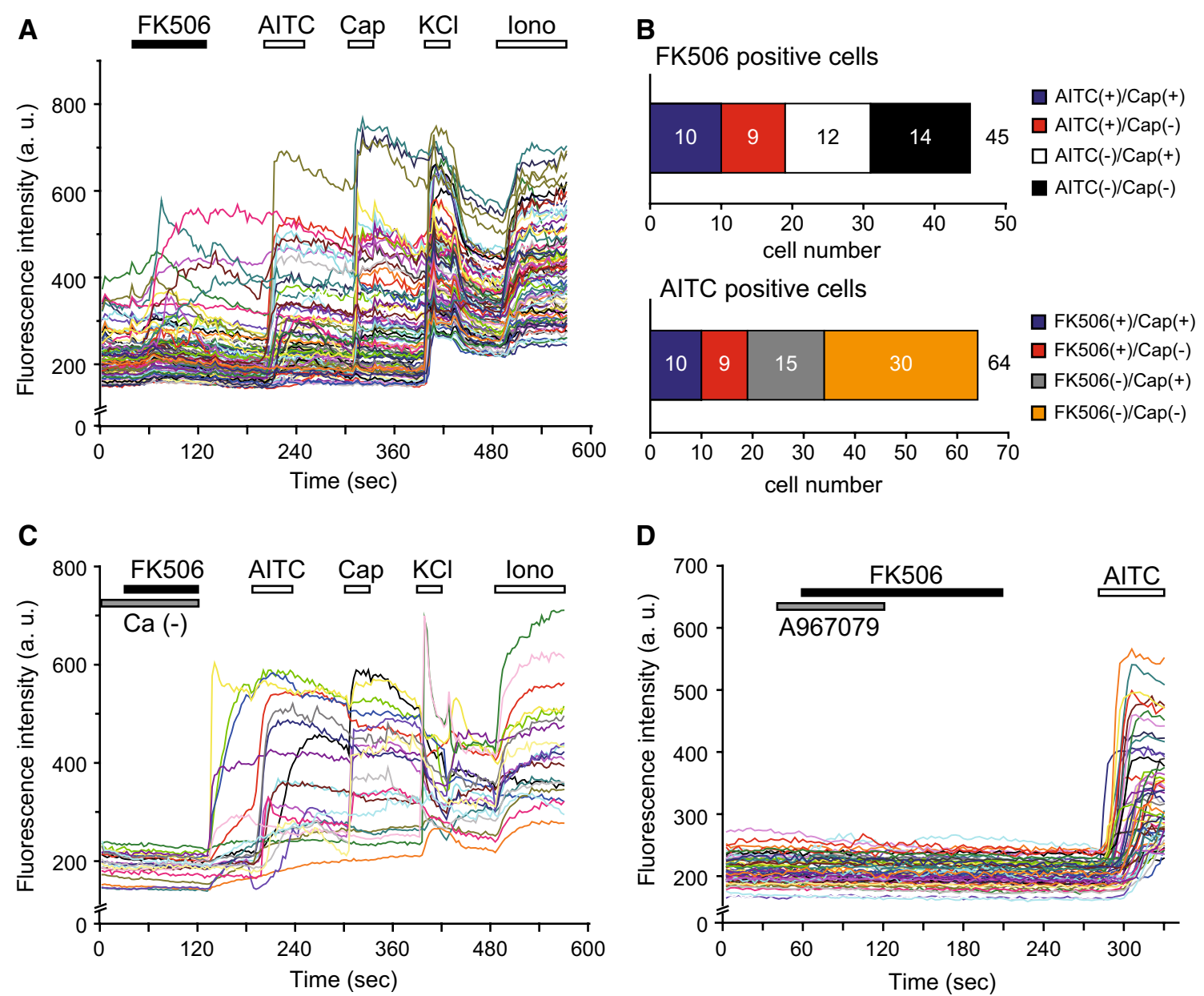

Fig. 5 Increases in intracellular $\mathrm{Ca}^{2+}$ concentration induced by FK506 in mouse dorsal root ganglion neurons. a Representative traces of changes in intracellular $\mathrm{Ca}^{2+}$ concentrations $\left(\left[\mathrm{Ca}^{2+}\right]_{\mathrm{i}}\right)$ induced by $30 \mu \mathrm{M}$ FK506 in mouse dorsal root ganglion (DRG) neurons. Mouse DRG neurons were categorized by $100 \mu \mathrm{M}$ AITC and $1 \mu \mathrm{M}$ capsaicin (Cap). Neurons were determined by $50 \mathrm{mM} \mathrm{KCl}$ and cell viability was confirmed by $5 \mu \mathrm{M}$ ionomycin (Iono). Y-axis: fluorescence intensity of Fluo-4. b Classification of mouse DRG neu-

IL-1 $\beta$, IL-6) and NGF in DRG in a chronic constriction injury (CCI) model of rats [54], but it did not affect acute pain [55]. Inhibition of calcineurin and NFAT2 by A kinase anchor protein 150 (AKAP150) downregulated IL-4 in DRG during paclitaxel-induced neuropathic pain, but AKAP150 was not involved in acute pain in rodents [56]. In this study, we found that local injection of FK506 induced acute licking or biting behaviors and these behaviors were impaired in TRPA1KO mice (Fig. 6b). Furthermore, FK506 increased $\left[\mathrm{Ca}^{2+}\right]_{i}$ in TRPA1-expressing primary sensory neurons (Fig. 5a, b). Taken together, we conclude that FK506-induced licking or biting behaviors are caused by the activation of TRPA1 expressed in primary sensory neurons and that the mechanism of acute irritation is different from that of chronic pain.

rons depending on the response to $30 \mu \mathrm{M}$ FK506 and $100 \mu \mathrm{M}$ AITC. A total of 186 neurons were obtained from three mice. The $\mathrm{X}$-axis indicates the number of cells. $\mathbf{c}\left[\mathrm{Ca}^{2+}\right]_{\mathrm{i}}$ increases induced by $30 \mu \mathrm{M}$ FK506 were almost abolished in the absence of extracellular $\mathrm{Ca}^{2+}$ $(\mathrm{Ca}(-))$. d $\left[\mathrm{Ca}^{2+}\right]_{\mathrm{i}}$ increases induced by $30 \mu \mathrm{M}$ FK506 were inhibited by $3 \mu \mathrm{M}$ A967079, a TRPA1 antagonist, in the mouse DRG neurons responded to $100 \mu \mathrm{M}$ AITC

Some reports demonstrated the involvement of TRP channels in FK506-related sensations of pain and itch. FK506-induced pancreatitis-related pain was attenuated by an antagonist of TRPV1, but not by voltage-gated $\mathrm{Ca}^{2+}$ channels in mice [44]. FK506 enhanced TRPA1 expression in a murine model of oxazolone-induced chronic hypersensitivity and FK506-induced scratching behaviors were reduced by a TRPA1 antagonist [57]. In this study, we found that local injection of FK506 induced acute licking or biting behaviors through TRPA1 activation (Fig. 6a, b). Licking and biting behaviors are usually interpreted as chemical-induced acute pain-related behaviors. However, some reports showed that biting behaviors are rather related to itch sensation $[58,59]$. In patients with atopic dermatitis, it is known that FK506 ointment causes 

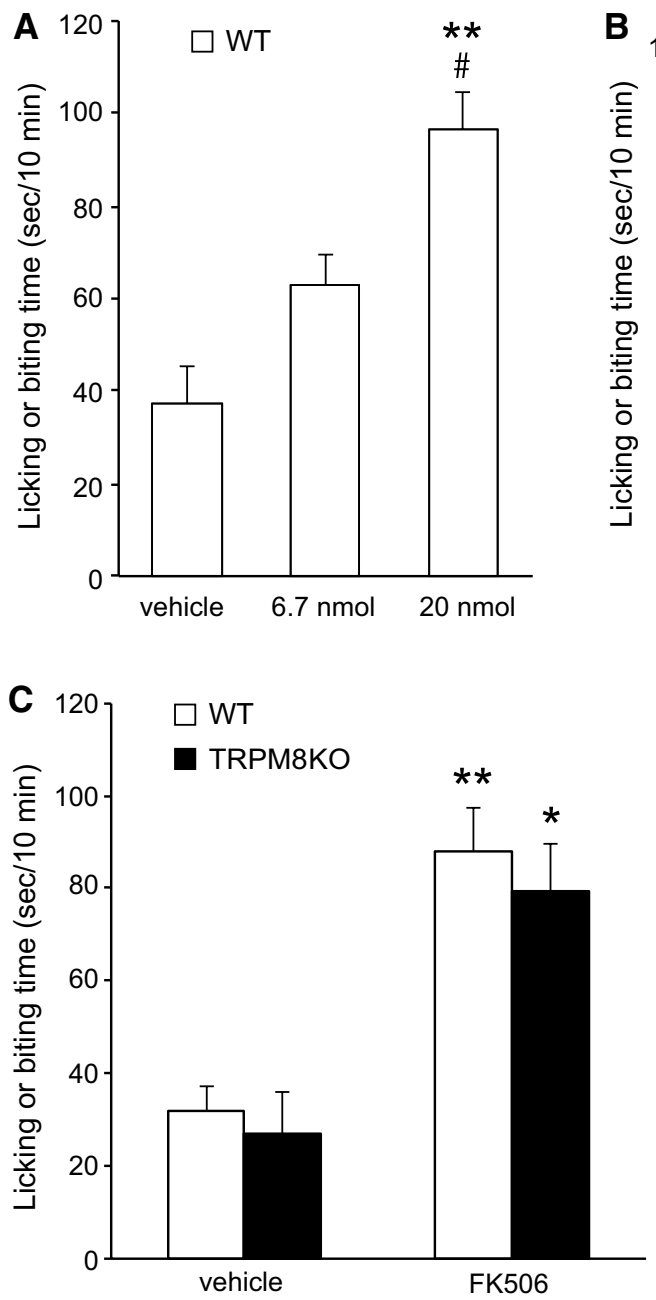
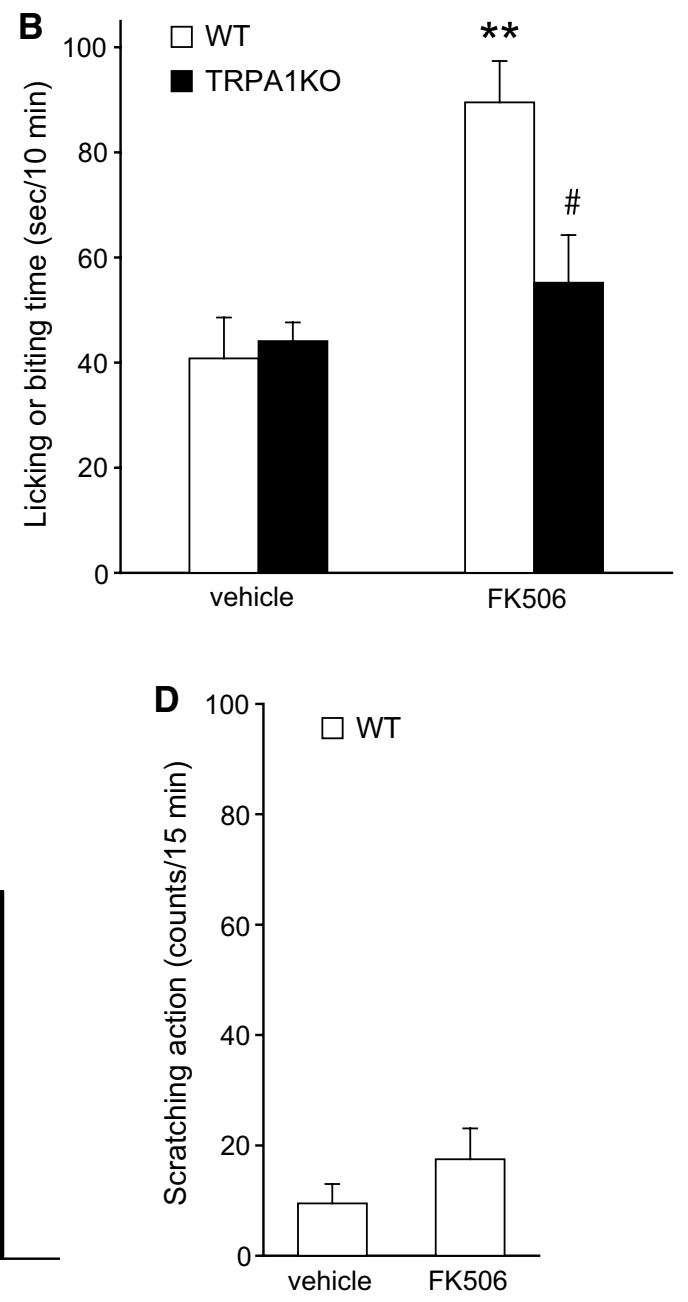

Fig. 6 Pain-related and itch-related behaviors induced by FK506 in mice. a Time spent by wild-type (WT) mice licking or biting in the $10 \mathrm{~min}$ following intraplantar injection of vehicle, $6.7 \mathrm{nmol} \mathrm{FK506}$ or 20 nmol FK506. Each column represents the mean + SEM from 7 to 9 mice. Statistical analysis was performed using ANOVA followed by a two-tailed multiple $t$ test with Bonferroni correction. **, $P<0.01$ vs. vehicle; \#, $P<0.05$ vs. $6.7 \mathrm{nmol}$. b Time spent by WT or TRPA1 knockout (TRPA1KO) mice licking or biting in the 10 min following intraplantar injection of vehicle or $20 \mathrm{nmol}$ FK506. Each column represents the mean + SEM from 8 or 9 mice. Statistical analysis was performed using ANOVA followed by a two-tailed multiple $t$ test

transient burning pain or itch sensations at the site of application $[12,60]$. The most common expression of local irritative symptoms is a burning sensation [12-14], and pruritus seemed to be related to burning sensations [12]. While it is difficult to distinguish between pain and itch sensation in mouse models, our data suggest that FK506 causes pain rather than itching sensations. Our finding that scratching behaviors were not induced by FK506 could support this idea (Fig. 6d). Thus, skin irritation by FK506 ointment could be caused by TRPA1 activation. with Bonferroni correction. **, $P<0.01$ vs. vehicle; \#, $P<0.01$ vs. WT. c Time spent by WT or TRPM8 knockout (TRPM8KO) mice licking or biting in the $10 \mathrm{~min}$ following intraplantar injection of vehicle or 20 nmol FK506. Each column represents the mean + SEM from 6 to 9 mice. Statistical analysis was performed using ANOVA followed by a two-tailed multiple $t$ test with Bonferroni correction. $*, P<0.05, * *, P<0.01$ vs. vehicle. d The number of incidents of scratching following intradermal injection of vehicle or $20 \mathrm{nmol}$ FK506 into the back skin over a 15-min period. Each column represents the mean + SEM from 6 mice

Acknowledgements We thank Dr. Mitsutoki Hatta from Fukuoka Dental College for helpful discussion, and Ms. N. Fukuta from the National Institute for Physiological Sciences for technical assistance.

Funding The present study was supported by a grant from Maruho Co., Ltd.

\section{Compliance with ethical standards}

Conflict of interest The authors declare that they have no conflicts of interest. 
Statement on the welfare of animals All applicable international, national, and/or institutional guidelines for the care and use of animals were followed. All procedures performed in studies involving animals were in accordance with the ethical standards of the institution or practice at which the studies were conducted.

\section{References}

1. Flanagan WM, Corthésy B, Bram RJ, Crabtree GR (1991) Nuclear association of a T-cell transcription factor blocked by FK-506 and cyclosporin A. Nature 352:803-807

2. Liu J, Farmer JD Jr, Lane WS, Friedman J, Weissman I, Schreiber SL (1991) Calcineurin is a common target of cyclophilin-cyclosporin A and FKBP-FK506 complexes. Cell 66:807-815

3. Schreiber SL, Crabtree GR (1992) The mechanism of action of cyclosporin A and FK506. Immunol Today 13:136-142

4. Svensson A, Chambers C, Gånemo A, Mitchell SA (2011) A systematic review of tacrolimus ointment compared with corticosteroids in the treatment of atopic dermatitis. Curr Med Res Opin 27:1395-1406

5. Rustin MH (2007) The safety of tacrolimus ointment for the treatment of atopic dermatitis: a review. Br J Dermatol 157:861-873

6. Saeki H (2017) Management of atopic dermatitis in Japan. J Nippon Med Sch 84:2-11

7. Alomar A, Berth-Jones J, Bos JD, Giannetti A, Reitamo S, Ruzicka T, Stalder JF, Thestrup-Pedersen K (2004) The role of topical calcineurin inhibitors in atopic dermatitis. $\mathrm{Br} \mathrm{J}$ Dermatol 151(Suppl 70):3-27

8. Sakuma S, Higashi Y, Sato N, Sasakawa T, Sengoku T, Ohkubo Y, Amaya T, Goto T (2001) Tacrolimus suppressed the production of cytokines involved in atopic dermatitis by direct stimulation of human PBMC system. (Comparison with steroids). Int Immunopharmacol 1:1219-1226

9. Kato A, Chustz RT, Ogasawara T, Kulka M, Saito H, Schleimer RP, Matsumoto K (2009) Dexamethasone and FK506 inhibit expression of distinct subsets of chemokines in human mast cells. J Immunol 182:7233-7243

10. Hanifin JM, Paller AS, Eichenfield L, Clark RA, Korman N, Weinstein G, Caro I, Jaracz E, Rico MJ (2005) Efficacy and safety of tacrolimus ointment treatment for up to 4 years in patients with atopic dermatitis. J Am Acad Dermatol 53:S186-S194

11. Cury Martins J, Martins C, Aoki V, Gois AF, Ishii HA, da Silva EM (2015) Topical tacrolimus for atopic dermatitis. Conhrane Datab Syst Rev 7:Cd009864

12. Reitamo S, Wollenberg A, Schopf E, Perrot JL, Marks R, Ruzicka T, Christophers E, Kapp A, Lahfa M, Rubins A, Jablonska S, Rustin M (2000) Safety and efficacy of 1 year of tacrolimus ointment monotherapy in adults with atopic dermatitis. The European Tacrolimus Ointment Study Group. Arch Dermatol 136:999-1006

13. Housman TS, Norton AB, Feldman SR, Fleischer AB Jr, Simpson EL, Hanifin JM, Antaya RJ (2004) Tacrolimus ointment: utilization patterns in children under age 2 years. Dermatol Online J 10:2

14. Reitamo S, Rustin M, Ruzicka T, Cambazard F, Kalimo K, Friedmann PS, Schoepf E, Lahfa M, Diepgen TL, Judodihardjo $\mathrm{H}$, Wollenberg A, Berth-Jones J, Bieber T, European Tacrolimus Ointment Study G (2002) Efficacy and safety of tacrolimus ointment compared with that of hydrocortisone butyrate ointment in adult patients with atopic dermatitis. J Allergy Clin Immunol 109:547-555

15. Christensen AP, Corey DP (2007) TRP channels in mechanosensation: direct or indirect activation? Nat Rev Neurosci 8:510-521

16. Minke B, Cook B (2002) TRP channel proteins and signal transduction. Physiol Rev 82:429-472
17. Zhang XF, Chen J, Faltynek CR, Moreland RB, Neelands TR (2008) Transient receptor potential A1 mediates an osmotically activated ion channel. Eur J Neurosci 27:605-611

18. Tominaga M (2007) The role of TRP channels in thermosensation. In: Liedtke WB, Heller S (eds) TRP ion channel function in sensory transduction and cellular signaling cascades. CRC Press, Boca Raton

19. Vriens J, Owsianik G, Hofmann T, Philipp SE, Stab J, Chen X, Benoit M, Xue F, Janssens A, Kerselaers S, Oberwinkler J, Vennekens R, Gudermann T, Nilius B, Voets T (2011) TRPM3 is a nociceptor channel involved in the detection of noxious heat. Neuron 70:482-494

20. Tan CH, McNaughton PA (2016) The TRPM2 ion channel is required for sensitivity to warmth. Nature 536:460-463

21. Story GM, Peier AM, Reeve AJ, Eid SR, Mosbacher J, Hricik TR, Earley TJ, Hergarden AC, Andersson DA, Hwang SW, McIntyre P, Jegla T, Bevan S, Patapoutian A (2003) ANKTM1, a TRP-like channel expressed in nociceptive neurons, is activated by cold temperatures. Cell 112:819-829

22. Fujita F, Uchida K, Moriyama T, Shima A, Shibasaki K, Inada H, Sokabe T, Tominaga M (2008) Intracellular alkalization causes pain sensation through activation of TRPA1 in mice. J Clin Invest 118:4049-4057

23. Zurborg S, Yurgionas B, Jira JA, Caspani O, Heppenstall PA (2007) Direct activation of the ion channel TRPA1 by $\mathrm{Ca}^{2+}$. Nat Neurosci 10:277-279

24. Hu H, Bandell M, Petrus MJ, Zhu MX, Patapoutian A (2009) Zinc activates damage-sensing TRPA1 ion channels. Nat Chem Biol 5:183-190

25. Jordt SE, Bautista DM, Chuang HH, McKemy DD, Zygmunt PM, Högestätt ED, Meng ID, Julius D (2004) Mustard oils and cannabinoids excite sensory nerve fibres through the TRP channel ANKTM1. Nature 427:260-265

26. Okumura $Y$, Narukawa M, Iwasaki Y, Ishikawa A, Matsuda H, Yoshikawa M, Watanabe T (2010) Activation of TRPV1 and TRPA1 by black pepper components. Biosci Biotechnol Biochem 74:1068-1072

27. Macpherson LJ, Geierstanger BH, Viswanath V, Bandell M, Eid SR, Hwang S, Patapoutian A (2005) The pungency of garlic: activation of TRPA1 and TRPV1 in response to allicin. Curr Biol 15:929-934

28. Bandell M, Story GM, Hwang SW, Viswanath V, Eid SR, Petrus MJ, Earley TJ, Patapoutian A (2004) Noxious cold ion channel TRPA 1 is activated by pungent compounds and bradykinin. Neuron 41:849-857

29. Peyrot des Gachons C, Uchida K, Bryant B, Shima A, Sperry JB, Dankulich-Nagrudny L, Tominaga M, Smith AB 3rd, Beauchamp GK, Breslin PA (2011) Unusual pungency from extravirgin olive oil is attributable to restricted spatial expression of the receptor of oleocanthal. J Neurosci 31:999-1009

30. Koo JY, Jang Y, Cho H, Lee CH, Jang KH, Chang YH, Shin J, Oh U (2007) Hydroxy-alpha-sanshool activates TRPV1 and TRPA1 in sensory neurons. Eur J Neurosci 26:1139-1147

31. Corey DP, Garcia-Anoveros J, Holt JR, Kwan KY, Lin SY, Vollrath MA, Amalfitano A, Cheung EL, Derfler BH, Duggan A, Geleoc GS, Gray PA, Hoffman MP, Rehm HL, Tamasauskas D, Zhang DS (2004) TRPA1 is a candidate for the mechanosensitive transduction channel of vertebrate hair cells. Nature 432:723-730

32. Kwan KY, Allchorne AJ, Vollrath MA, Christensen AP, Zhang DS, Woolf CJ, Corey DP (2006) TRPA1 contributes to cold, mechanical, and chemical nociception but is not essential for haircell transduction. Neuron 50:277-289

33. Fujita F, Uchida K, Takayama Y, Suzuki Y, Takaishi M, Tominaga M (2018) Hypotonicity-induced cell swelling activates TRPA1. J Physiol Sci 68:431-440 
34. Caspani O, Heppenstall PA (2009) TRPA1 and cold transduction: an unresolved issue? J Gen Physiol 133:245-249

35. Karashima Y, Talavera K, Everaerts W, Janssens A, Kwan KY, Vennekens R, Nilius B, Voets T (2009) TRPA1 acts as a cold sensor in vitro and in vivo. Proc Natl Acad Sci U S A 106:1273-1278

36. Fujita F, Moriyama T, Higashi T, Shima A, Tominaga M (2007) Methyl $p$-hydroxybenzoate causes pain sensation through activation of TRPA1 channels. Br J Pharmacol 151:153-160

37. Maher M, Ao H, Banke T, Nasser N, Wu NT, Breitenbucher JG, Chaplan SR, Wickenden AD (2008) Activation of TRPA1 by farnesyl thiosalicylic acid. Mol Pharmacol 73:1225-1234

38. Karashima Y, Damann N, Prenen J, Talavera K, Segal A, Voets T, Nilius B (2007) Bimodal action of menthol on the transient receptor potential channel TRPA1. J Neurosci 27:9874-9884

39. Fischer MJ, Leffler A, Niedermirtl F, Kistner K, Eberhardt M, Reeh PW, Nau C (2010) The general anesthetic propofol excites nociceptors by activating TRPV1 and TRPA 1 rather than GABAA receptors. J Biol Chem 285:34781-34792

40. Piao LH, Fujita T, Jiang CY, Liu T, Yue HY, Nakatsuka T, Kumamoto E (2009) TRPA1 activation by lidocaine in nerve terminals results in glutamate release increase. Biochem Biophys Res Commun 379:980-984

41. Uchida K, Miura Y, Nagai M, Tominaga M (2012) Isothiocyanates from Wasabia japonica activate transient receptor potential ankyrin 1 channel. Chem Senses 37:809-818

42. Kuraishi Y, Nagasawa T, Hayashi K, Satoh M (1995) Scratching behavior induced by pruritogenic but not algesiogenic agents in mice. Eur J Pharmacol 275:229-233

43. Senba E, Katanosaka K, Yajima H, Mizumura K (2004) The immunosuppressant FK506 activates capsaicin- and bradykininsensitive DRG neurons and cutaneous C-fibers. Neurosci Res 50:257-262

44. Terada Y, Tsubota M, Sugo H, Wakitani K, Sekiguchi F, Wada K, Takada M, Oita A, Kawabata A (2017) Tacrolimus triggers transient receptor potential vanilloid-1-dependent relapse of pancreatitis-related pain in mice. Pharmacology 99:281-285

45. Pereira U, Boulais N, Lebonvallet N, Pennec JP, Dorange G, Misery L (2010) Mechanisms of the sensory effects of tacrolimus on the skin. Br J Dermatol 163:70-77

46. Nagatomo K, Kubo Y (2008) Caffeine activates mouse TRPA1 channels but suppresses human TRPA1 channels. Proc Natl Acad Sci U S A 105:17373-17378

47. Takahashi N, Kuwaki T, Kiyonaka S, Numata T, Kozai D, Mizuno Y, Yamamoto S, Naito S, Knevels E, Carmeliet P, Oga T, Kaneko S, Suga S, Nokami T, Yoshida J, Mori Y (2011) TRPA1 underlies a sensing mechanism for O2. Nat Chem Biol 7:701-711

48. Sinkins WG, Goel M, Estacion M, Schilling WP (2004) Association of immunophilins with mammalian TRPC channels. J Biol Chem 279:34521-34529

49. Kobayashi K, Fukuoka T, Obata K, Yamanaka H, Dai Y, Tokunaga A, Noguchi K (2005) Distinct expression of TRPM8, TRPA1, and TRPV1 mRNAs in rat primary afferent neurons with adelta/cfibers and colocalization with trk receptors. J Comp Neurol 493:596-606

50. Elg S, Marmigere F, Mattsson JP, Ernfors P (2007) Cellular subtype distribution and developmental regulation of TRPC channel members in the mouse dorsal root ganglion. J Comp Neurol 503:35-46

51. Zimmermann K, Lennerz JK, Hein A, Link AS, Kaczmarek JS, Delling M, Uysal S, Pfeifer JD, Riccio A, Clapham DE (2011) Transient receptor potential cation channel, subfamily $\mathrm{C}$, member 5 (TRPC5) is a cold-transducer in the peripheral nervous system. Proc Natl Acad Sci USA 108:18114-18119

52. Franco M, Blaimont A, Albano L, Bendini C, Cassuto E, Jaeger $P$ (2004) Tacrolimus pain syndrome in renal transplant patients: report of two cases. Joint Bone Spine 71:157-159

53. Ishida S, Kato M, Fujita T, Funahashi Y, Sassa N, Matsukawa Y, Yoshino Y, Yamamoto T, Katsuno T, Maruyama S, Gotoh M (2017) Calcineurin inhibitor-induced pain syndrome in ABOincompatible living kidney transplantation: a case report. Transpl Proc 49:163-166

54. Yu HM, Wang Q, Sun WB (2017) Silencing of FKBP51 alleviates the mechanical pain threshold, inhibits DRG inflammatory factors and pain mediators through the NF-kappaB signaling pathway. Gene 627:169-175

55. Maiaru M, Tochiki KK, Cox MB, Annan LV, Bell CG, Feng X, Hausch F, Geranton SM (2016) The stress regulator FKBP51 drives chronic pain by modulating spinal glucocorticoid signaling. Sci Transl Med 8:325ra19

56. Nie B, Liu C, Bai X, Chen X, Wu S, Zhang S, Huang Z, Xie M, Xu T, Xin W, Zeng W, Ouyang H (2018) AKAP150 involved in paclitaxel-induced neuropathic pain via inhibiting $\mathrm{CN} /$ NFAT2 pathway and downregulating IL-4. Brain Behav Immun 68:158-168

57. Wong LS, Otsuka A, Yamamoto Y, Nonomura Y, Nakashima C, Kitayama N, Usui K, Honda T, Kabashima K (2018) TRPA1 channel participates in tacrolimus-induced pruritus in a chronic contact hypersensitivity murine model. J Dermatol Sci 89:207-209

58. Hagiwara K, Nojima H, Kuraishi Y (1999) Serotonin-induced biting of the hind paw is itch-related response in mice. Pain Research 14:53-59

59. Akiyama T, Nagamine M, Carstens MI, Carstens E (2014) Behavioral model of itch, alloknesis, pain and allodynia in the lower hindlimb and correlative responses of lumbar dorsal horn neurons in the mouse. Neuroscience 266:38-46

60. Saeki H, Furue M, Furukawa F, Hide M, Ohtsuki M, Katayama I, Sasaki R, Suto H, Takehara K, CfGftMoADoJD ASSOCIATION (2009) Guidelines for management of atopic dermatitis. J Dermatol 36:563-577 